IRA-International Journal of Management \& Social Sciences

ISSN 2455-2267; Vol.06, Issue 02 (2017)

Pg. no. 324-331

Institute of Research Advances

https://research-advances.org/index.php/RAJMSS

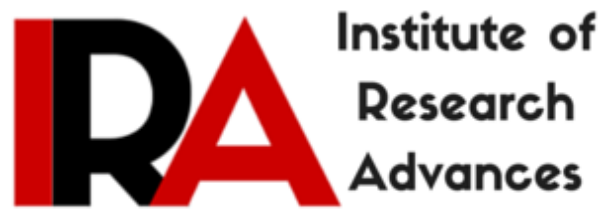

\title{
Financial Inclusion through Islamic Banking
}

\author{
Mumna Nazar \\ Assistant Professor, P.G Dept. of Commerce, MES Asmabi College, P. Vemballur, India. \\ Type of Review: Peer Reviewed. \\ DOI: http://dx.doi.org/10.21013/jmss.v6.n2.p17
}

\section{How to cite this paper:}

Nazar, M. (2017). Financial Inclusion through Islamic Banking. IRA-International Journal of Management \& Social Sciences (ISSN 2455-2267), 6(2), 324-331. doi:http://dx.doi.org/10.21013/jmss.v6.n2.p17

(C) Institute of Research Advances

\section{(cc) BY-NC}

This work is licensed under a Creative Commons Attribution-Non Commercial 4.0 International License subject to proper citation to the publication source of the work.

Disclaimer: The scholarly papers as reviewed and published by the Institute of Research Advances (IRA) are the views and opinions of their respective authors and are not the views or opinions of the IRA. The IRA disclaims of any harm or loss caused due to the published content to any party. 


\section{ABSTRACT}

Financial inclusion is a buzz word today. It plays an important role in driving away the poverty from the country. Financial inclusion is the process of ensuring financial services to the weaker sections of the society at an affordable cost. As per the Sachar Committee Report, Muslims in India are financially excluded. Even though they have an account, the extent of usage is very low due to the religious reasons. The NonMuslims also do not actively engage in the formal financial system due to the interest involvement. Islamic Bank can serve as a remedy for the financial exclusion of the Muslims as well as Non-Muslims community. The objective of this paper is to understand the extent of financial inclusion among the people in Kerala and their awareness and preference towards Islamic banking. Both primary and secondary data are collected for the study. Secondary data are collected from various secondary sources like published articles, journals, reports, books and websites. Primary data are collected with the help of questionnaire among people in Kerala. The study revealed that most of the respondents have accessed bank accounts but the extent of usage is only for namesake. Moreover the awareness and preference towards Islamic Banking is very high among the Muslims as well as Non-Muslims and suggested that proper care must be taken for introducing Islamic banking system in India. It will ultimately leads to the inclusive growth of our country.

Keywords: Financial Inclusion, Financial Exclusion, Islamic banking, Inclusive Growth

\section{INTRODUCTION}

The cornerstone of Inclusive economic growth philosophy is that, the benefits of economic growth should be equitably spread across everybody in the country. No country in the world can take pride in the economic growth, when a large segment of the population of the country continues to be financially excluded. Financial inclusion played a major role in the economic development of a country through poverty eradication. Dr. C. Rangarajan Committee on Financial inclusion (2008), appointed by Govt. of India to study Financial inclusion, defined financial inclusion as "the process of ensuring access to appropriate financial products and services needed by all sections of the society in general, and vulnerable groups such as weaker sections and low income groups in particular, at an affordable cost".

India has the second largest Muslim population in the world. This segment of the population needs access to personal finance. Conventional banking products are not in accordance with their personal law and are not fully accepted by the market segment. A high level committee report known as the Sachar Committee Report in India had pointed out that certain sections of Muslims are very backward in India, and do not use the banking sector. Those who use the banking services are only for name sake. Majority of the Muslim population firmly believe interest as forbidden. The policy goal of financial inclusion can be met if financial products offered to Muslims are not repugnant to their personal law. Moreover, most of the Non-Muslims are not actively engage in the formal financial system. Majority of the people in India make use of the banking service only for fund transfer, safe keeping of their deposit etc. and they do not deposit their fund or avail loans from the bank due to the interest involvement. Here lies the importance of Islamic banking. The prospects for Islamic banks are very bright in Kerala especially when many of the Muslims deposit their savings in the conventional banks without accepting any interest. So a piece of research has been designed to evaluate the extent of financial inclusion among the population in Kerala as well as their awareness and preference towards Islamic banking.

\section{LITERATURE REVIEW}

(TP, 2014) made an attempt to study the the extent of financial inclusion among rural households. The study revealed that some of the rural households do not save regularly and does not access to credit.She suggested that the formal financial instituition should extent their hands to help the people regarding the financial aspects and change the existing policies. 
(Dr.Eugin Prakash Pathrose, 2015) discussed various challenges faced by customers in Financial inclusion.In the study they point out that the access and use of financial inclusion in India remains very low.It also shows that only $8 \%$ of the population took a new loan from a formal banking channel. They further states that $35 \%$ of adults in India have bank accounts when compared to the global average of $50 \%$.

(Minakshi, 2009) conducted study to assess the implementation of the financial inclusion drive and usage of banking services by households in Gulbarga district, Karnataka.It was found that though the number of households with bank accounts doubled over the duration of financial inclusion drive, $36 \%$ of the sample remained excluded from any kind of formal or semi formal saving account.

(Gupta, 2013) try to review the financial inclusion in Hoogly. The study focus on the extent of financial inclusion and finds that the rate of financial inclusion is only around 50\%. Households belonging to minority communities, backward classes, people working as agricultural labours, people who are below poverty line, illeterate were mostly excluded.

(Naveed Azeem Khattak, 2010) conducted a study to assess the customer satisfaction and awareness of Islamic banking. In the study they suggested that, the customer's awareness level towards Islamic banking is good. Moreover, the customers adopted Islamic Banking due to not only the religious reasons, but also due to bank efficiency in the transaction, their confidentiality to its customers, its working hours etc.

\section{SCOPE \& SIGNIFICANCE OF THE STUDY}

Muslims are largely excluded from mainstream financial services so far due to involvement of the interest element in these transactions. Interest is strictly prohibited in the monetary affairs according to the Islamic teachings. Non-Muslims also face many financial problem but they are not ready to take loans from bank due to the heavy interest rate. The government tried to take the financial services to each households of country. These steps of course have enlarged the banking and financial penetration level in India. In response of such initiatives, level of registration in mainstream banking has increased tremendously. But the most important part is the extent of benefit level. Besides the number of account, level of transaction and availability of credit facilities should also increased so that poor people can have the access of such services for their financing needs. This paper is an attempt to study the extent of financial inclusion and the awareness and preference towards Islamic banking among people in Kerala.

\section{OBJECTIVES OF THE STUDY}

1. To assess the extent of financial inclusion among people in Kerala.

2. To assess the awareness and preference towards Islamic banking among Public in Kerala.

3. To test whether there is any disagreement between Muslims and Non Muslims regarding the awareness $\&$ Preference towards Islamic Banking.

\section{HYPOTHESIS}

1. There is no significant difference between Muslims and Non- Muslims regarding the awareness about Islamic Banking.

2. There is no significant difference between Muslims and Non- Muslims regarding the preference towards Islamic Banking.

\section{RESEARCH METHODOLOGY}

Both primary data and secondary data are used for the study. As per the CRISIL Inclusix Index, out of 638 districts in India Malappuram is ranked $124^{\text {th }}$ position in financial inclusion. Therefore for primary data 
collection, 50 Muslims and 50 Non- Muslims from Malappuram District were selected by using convenience sampling method. Total number of samples is limited to 100 due to shortage of time. Structured questionnaire is used for data collection. Secondary data are collected from various secondary sources like published articles, journals, reports, books and websites. For analysis of data, percentage method is used. For testing hypothesis Chi square test is used.

\section{FINANCIAL INCLUSION IN KERALA}

Indian government has initiated several programs recently to expand the circle of financial inclusion. The major steps include Pradhan Mantri Jan Dhan Yojana, compulsion of banking account for scholarship schemes, MGNREGA, other cash benefit schemes, introduction of Aadhar, Pradhan Mantri Suraksha Bima Yojana, Pradhan Mantri Jeevan Jyoti Bima Yojana, banking correspondents, IT based applications, simplifying KYC norms, no frill accounts, Kisan credit cards etc. Kerala, a Southern state in India, has witnessed high social development, disproportionate to the economic growth. The social parameters of literacy, longevity, per capita income etc. in Kerala is highest in the country. The Kerala experience in this regard has been famously referred to as the 'Kerala model of development', by International economists like Amartya Sen. The ranking of 14 districts in India in this regard according to the CRISIL Inclusix Index is as follows:

\begin{tabular}{|l|l|l|l|l|l|}
\hline District & $\begin{array}{l}\text { Ranking in } \\
\text { the Country }\end{array}$ & District & $\begin{array}{l}\text { Ranking in the } \\
\text { Country }\end{array}$ & District & $\begin{array}{l}\text { Ranking in } \\
\text { the Country }\end{array}$ \\
\hline Pathanamthitta & 1 & Alappuzha & 11 & Wayanad & 24 \\
\hline Trissur & 3 & Kasargod & 20 & Kannur & 32 \\
\hline Ernakulam & 4 & Kollam & 43 & Kozhikode & 33 \\
\hline Thiruvananthapuram & 5 & Malappuram & 124 & Palaghat & 37 \\
\hline Kottayam & 7 & Idukki & 44 & & \\
\hline
\end{tabular}

Source: Crisil-Inclusix Index, Ranking of 638districts in all states in India.

\section{RESULTS AND DISCUSSION}

Demographic information of the respondents is given below.

Table No. 1 Demographic Profile of the Respondents

\begin{tabular}{|c|c|c|c|c|c|}
\hline $\begin{array}{c}\text { Demographic } \\
\text { Variable }\end{array}$ & Frequency & Percentage & $\begin{array}{c}\text { Demographic } \\
\text { Variable } \\
\end{array}$ & Frequency & Percentage \\
\hline \multicolumn{3}{|l|}{ Gender } & \multicolumn{3}{|l|}{ Occupation } \\
\hline Male & 72 & 72 & Self Employed & 42 & 42 \\
\hline Female & 28 & 28 & Professional & 12 & 12 \\
\hline Total & 100 & 100 & Govt. Employee & 22 & 22 \\
\hline \multicolumn{3}{|l|}{ Age } & Others & 24 & 24 \\
\hline $18-30$ & 18 & 18 & Total & 100 & 100 \\
\hline $31-45$ & 44 & 44 & \multicolumn{3}{|l|}{ Annual Income } \\
\hline $46-60$ & 32 & 32 & Up to 100000 & 40 & 40 \\
\hline 61 or Above & 6 & 6 & $100001-250000$ & 28 & 28 \\
\hline Total & 100 & 100 & $250001-400000$ & 20 & 20 \\
\hline \multicolumn{3}{|l|}{ Education } & 400001 or above & 12 & 12 \\
\hline Plus Two & 12 & 12 & Total & 100 & 100 \\
\hline Graduate & 38 & 38 & \multicolumn{3}{|l|}{ Religion } \\
\hline Post Graduate & 14 & 14 & Muslims & 50 & 50 \\
\hline Others & 36 & 36 & Non Muslims & 50 & 50 \\
\hline Total & 100 & 100 & Total & 100 & 100 \\
\hline
\end{tabular}

Source: Primary Data 
Out of the total respondents $72 \%$ are male and $28 \%$ are female. $44 \%$ of the respondents are aged between $31-45.38 \%$ of the respondents are Graduate. Most of the respondents are self employed and having less than Rs.100000/- income.

Table No. 2 Reasons for having and not having bank accounts

\begin{tabular}{|c|c|c|c|c|}
\hline \multicolumn{5}{|c|}{ Reasons for having bank account } \\
\hline \multirow[t]{2}{*}{ Reasons } & \multicolumn{2}{|c|}{ Frequency } & \multicolumn{2}{|c|}{ Percentage } \\
\hline & Muslims & $\begin{array}{c}\text { Non- } \\
\text { Muslims }\end{array}$ & Muslims & Non-Muslims \\
\hline For depositing & 4 & 4 & 8 & 8 \\
\hline For availing loan & 3 & 8 & 6 & 16 \\
\hline For fund transfer & 18 & 21 & 36 & 42 \\
\hline For safekeeping & 8 & 5 & 16 & 10 \\
\hline For satisfying the legal formalities & 15 & 12 & 30 & 24 \\
\hline For earning Interest & 0 & 0 & 0 & 0 \\
\hline Total & 48 & 50 & 96 & 100 \\
\hline \multicolumn{5}{|c|}{ Reasons for not having bank account } \\
\hline \multirow[t]{2}{*}{ Reasons } & \multicolumn{2}{|c|}{ Frequency } & \multicolumn{2}{|c|}{ Percentage } \\
\hline & Muslims & $\begin{array}{c}\text { Non- } \\
\text { Muslims }\end{array}$ & Muslims & Non-Muslims \\
\hline Not Needed & 2 & 0 & 4 & 0 \\
\hline Not enough money & 0 & 0 & 0 & 0 \\
\hline Religious reasons & 0 & 0 & 0 & 0 \\
\hline Procedural formalities & 0 & 0 & 0 & 0 \\
\hline Lack of financial knowledge & 0 & 0 & 0 & 0 \\
\hline Total & 2 & 0 & 4 & 0 \\
\hline Grant Total & 50 & 50 & 100 & 100 \\
\hline
\end{tabular}

\section{Source: Primary Data}

$100 \%$ of the Non-Muslims have bank account but only $96 \%$ of the Muslims have bank account. Most of the respondents are opened account for fund transfer and satisfying legal formalities like salary account, Adhaar, Subsidies etc. 16\% of the Muslims \& $10 \%$ of the Non-Muslims opened their account for safekeeping of deposits. Only $8 \%$ of the respondents from both categories are opened their account for the purpose of depositing.

Table No. 3 Reasons for having and not having Access to Credit

\begin{tabular}{|c|c|c|c|c|}
\hline \multicolumn{5}{|c|}{ Reasons for having Access to Credit } \\
\hline \multirow[t]{2}{*}{ Reasons } & \multicolumn{2}{|c|}{ Frequency } & \multicolumn{2}{|c|}{ Percentage } \\
\hline & Muslims & $\begin{array}{c}\text { Non- } \\
\text { Muslims }\end{array}$ & Muslims & $\begin{array}{c}\text { Non- } \\
\text { Muslims }\end{array}$ \\
\hline Children Education & 1 & 9 & 2 & 18 \\
\hline Uncertainty related to health & 0 & 0 & 0 & 0 \\
\hline Households needs & 8 & 0 & 16 & 0 \\
\hline Investment in business & 7 & 9 & 14 & 18 \\
\hline Total & 16 & 18 & 32 & 36 \\
\hline \multicolumn{5}{|c|}{ Reasons for not having Access to Credit } \\
\hline \multirow[t]{2}{*}{ Reasons } & \multicolumn{2}{|c|}{ Frequency } & \multicolumn{2}{|c|}{ Percentage } \\
\hline & Muslims & $\begin{array}{c}\text { Non- } \\
\text { Muslims }\end{array}$ & Muslims & $\begin{array}{c}\text { Non- } \\
\text { Muslims }\end{array}$ \\
\hline No Collaterals & 0 & 0 & 0 & 0 \\
\hline No guarantor & 0 & 0 & 0 & 0 \\
\hline Never needed & 11 & 12 & 22 & 24 \\
\hline
\end{tabular}




\begin{tabular}{|l|c|c|c|c|}
\hline Due to the interest involvement & 23 & 20 & 46 & 40 \\
\hline Procedural formalities & 0 & 0 & 0 & 0 \\
\hline Total & 34 & 32 & 68 & 64 \\
\hline Grant Total & 50 & 50 & 100 & 100 \\
\hline
\end{tabular}

Source: Primary Data

Out of the total respondents, only $34 \%$ of the respondents are borrowed from bank for household needs, investment in business etc. But more than $60 \%$ of the Muslims \&Non-Muslims are not borrowed from bank. The main reason for not access to credit is due to the interest involvement.

Table No. 4 Awareness \& Preference towards Islamic Banking

\begin{tabular}{|l|c|c|c|c|}
\hline \multicolumn{1}{|c|}{ Variables } & \multicolumn{2}{c|}{ Frequency } & \multicolumn{2}{c|}{ Percentage } \\
\cline { 2 - 5 } & Muslims & $\begin{array}{c}\text { Non- } \\
\text { Muslims }\end{array}$ & Muslims & $\begin{array}{c}\text { Non- } \\
\text { Muslims }\end{array}$ \\
\hline Aware & & 29 & 72 & 58 \\
\hline Not Aware & 14 & 21 & 28 & 42 \\
\hline Total & 50 & 50 & 100 & 100 \\
\hline Prefer & 50 & 48 & 100 & 96 \\
\hline Not Prefer & 0 & 2 & 0 & 4 \\
\hline Total & 50 & 50 & 100 & 100 \\
\hline
\end{tabular}

Source: Primary Data

$72 \%$ of the Muslims and $58 \%$ of the Non-Muslims are aware about the Islamic banking but $28 \%$ the Muslims and $42 \%$ of the Non-Muslims are not aware. Majority of the Muslims prefer the introduction of Islamic Banking in India. But only $4 \%$ of the Non-Muslims do not prefer Islamic Banking.

Table No. 5 Reasons for the preference towards Islamic Banking

\begin{tabular}{|l|c|c|c|c|}
\hline \multicolumn{1}{|c|}{ Reasons } & \multicolumn{2}{c|}{ Frequency } & \multicolumn{2}{c|}{ Percentage } \\
\cline { 2 - 5 } & Muslims & $\begin{array}{c}\text { Non- } \\
\text { Muslims }\end{array}$ & Muslims & $\begin{array}{c}\text { Non- } \\
\text { Muslims }\end{array}$ \\
\hline Religious Reason & 12 & 0 & 24 & 0 \\
\hline Socially Responsible investing & 6 & 10 & 12 & 20 \\
\hline Success story in the rest of the world & 2 & 10 & 4 & 20 \\
\hline Sustainability of profit-loss sharing model & 2 & 15 & 4 & 30 \\
\hline Interest free & 27 & 15 & 54 & 30 \\
\hline Variety Financial Products \& services & 1 & 0 & 2 & 0 \\
\hline Total & 50 & 50 & 100 & 100 \\
\hline
\end{tabular}

\section{Source: Primary Data}

Majority of the Muslim and Non-Muslims respondents prefer Islamic Banking due to its interest free nature.24\% Muslims show preference due to religious reasons and 30\% of the Non-Muslims prefer Islamic Banking because of profit-loss sharing model.

Table No. 6 Response to Introduction of Islamic Banking in India

\begin{tabular}{|l|c|c|c|c|}
\hline \multicolumn{1}{|c|}{ Response } & \multicolumn{2}{c|}{ Frequency } & \multicolumn{2}{c|}{ Percentage } \\
\cline { 2 - 5 } & Muslims & $\begin{array}{c}\text { Non- } \\
\text { Muslims }\end{array}$ & Muslims & $\begin{array}{c}\text { Non- } \\
\text { Muslims }\end{array}$ \\
\hline Open an account immediately with such type of bank & 37 & 30 & 74 & 60 \\
\hline Open an account after considering market response & 6 & 6 & 12 & 12 \\
\hline Continue with present banking system & 1 & 5 & 2 & 10 \\
\hline Can't say & 6 & 9 & 12 & 18 \\
\hline Total & 50 & 50 & 100 & 100 \\
\hline
\end{tabular}

\section{Source: Primary Data}

$74 \%$ of the Muslims and $60 \%$ of the Non-Muslims will open an account with the introduction of Islamic Banking but $12 \%$ from both categories will wait for the market response. 


\section{HYPOTHESIS TESTING}

* There is no significant difference between Muslims and Non- Muslims regarding the awareness about Islamic Banking.

The Chi square value is 2.16 and the table value is 3.84 . The Chi square value 2.16 is less than the table value at 5\% level of significance 3.84. Therefore, null hypothesis is accepted. So we can conclude that, there is no significant difference between Muslims and Non- Muslims regarding the awareness about Islamic Banking.

* There is no significant difference between Muslims and Non- Muslims regarding the preference towards Islamic Banking.

The Chi square value is 2.04 and the table value is 3.84 . The Chi square value 2.04 is less than the table value at $5 \%$ level of significance 3.84. Therefore, null hypothesis is accepted. So we can conclude that, there is no significant difference between Muslims and Non- Muslims regarding the preference towards Islamic Banking.

\section{MAJOR FINDINGS}

v The study reveals that $98 \%$ of the total respondents are included in the formal financial system in terms of access to bank account. So we can say that, majority are financially included.

$\checkmark$ Majority of the respondents use their bank account for fund transfer, safe keeping as well as for satisfying the legal formalities like obtaining subsidies, Adhaar Linkage, Salary Account etc. and neither for depositing not for borrowing. So we can summarize that the extent of financial inclusion is very poor in Kerala.

$\checkmark$ Out of the total respondents, only $34 \%$ of the respondents are borrowed from bank. But $66 \%$ of the people are not borrowed from bank. That means more than half of the population is financially excluded in terms of access to credit. The main reason for not access to credit is due to the interest involvement.

$\checkmark 65 \%$ of the total respondents are aware about the Islamic Banking and $98 \%$ of them prefer the introduction of Islamic Banking in India and the major reason for their preference is due to its interest free nature.

- $67 \%$ of the respondents open an account with the introduction of Islamic Banking but $12 \%$ will wait for the market response.

- Muslims and Non-Muslims are aware about Islamic Banking. Moreover, they uniformly prefer the introduction of Islamic Banking in India.

\section{SUGGESIONS AND CONCLUSION}

The Government of India and RBI strive to ensure that the poor people are included in the formal economy through banking channels. As compared to other states, Kerala is ranked in the first position in the list of financially included states. Majority of our people have bank accounts. But the extent of usage is very low. Actually they are not actively participated in the formal financial system due to the interest based banking. The study shows that if the Islamic Banking is introduced in India, definitely Muslims and Non-Muslims will actively participate in the banking system and we can ensure the overall inclusion of the people in the formal financial system. The criticizers of Islamic Banking point out that the introduction of Islamic Banking is not feasible in India because the legal framework of India is not allowing such a kind of banking system. But the United Kingdom which is the source of our constitution and banking laws, already adopted Islamic Banking due its immense opportunities for the future growth. There is three option for the Government of India to introduce Islamic Banking;(1)The amendment of the current legal framework (2)Establishment of a separate legislation for the functioning of Islamic Bank (3)Allow the foreign Islamic Banks to open their branches in India. Islamic Bank is the need of the hour and it will lead to the inclusive growth of India. 


\section{References}

1. Ahmad, Ausaf (1993), “Contemporary practice of Islamic financing techniques”, research paper No.20,Islamic Research and training Institute, Islamic Development Bank, Jeddah

2. Dr.Eugin Prakash Pathrose, A. B. (2015, January). A Study on the Challenges faced by customers in Financial Inclusion. International Journal of Scientific Research and Management , pp. 1989-1995.

3. Gafoor, A. A. (2012). Islamic Banking \& Finance. New Delhi: Islamic Book Service(P) Ltd.

4. Gupta, C. M. (2013). Financial Inclusion in Hoogly. Economic and Political weekly , 55-60.

5. Halim, Abdul, (1986), "Sources and uses of funds: a study of Bank Islam Malaysia Berhad," paper presented to the Seminar on Developing a System of Islamic Banking

6. Minakshi, R. (2009). Financial Inclusion in Gulberga:Finding usage in Access. Working Paper Series No.26 Centre for Micro finance. Chennai: Institute of Financial Managemnet and Research.

7. Naveed Azeem Khattak, K.-U.-R. (2010, May). Customer Satisfacion and awareness of Islamic banking system in Pakistan. African Journal of Business management , pp. 662-671.

8. TP, S. (2014, September). A Study on Extent of Financial Inclusion among Rural Households in Kerala. Internationl Journal of Economic and Business Review , pp. 106-112.

9. Usmani, Muhammad Taqi(1998), “An Introduction to Islamic Finance, Karachi”, Idaratul Ma'arif., pp. 132139.

10. Uzair, Muhammad(1955),"An Outline of Interest less Banking: Karachi/Dacca”, Raihan Publications.p-34 